\title{
THE RELATIONSHIP BETWEEN CORPORATE GOVERNANCE AND CORPORATE SOCIAL RESPONSIBILITY
}

\author{
Veres Edit \\ assistant professor \\ Partium Christian University, Faculty of Economics and Social Sciences, Department of Economics, Romania \\ veresedit@partium.ro
}

\begin{abstract}
Corporate governance $(C G)$ is a corporate governance system for large companies which includes policies and procedures for corporate social responsibility (CSR). The present study examines the relationships between CG and CSR, and analyzes the studies that separate or combine the explanation of the two concepts. CG can be interpreted as the relationship between governors and stakeholders. Angyal (2009) and Auer (2017) agree that the two phenomena coexist and are connected at several points. The goals of the two phenomena are intertwined, compliance with other important requirements (environmental, labor law) besides the primary corporate goal. $C G$ is a system based on the sharing of power and roles between owners, management and boards (board, supervisory board). The roles of ownership, supervision, and control are separated. The division of power means that the boards keep the management under strict control and the owners can account for the boards (Tasi, 2012). According to Tasi (2012), responsible CG involves careful management; financial planning and implementation; control mechanisms for the operation of the company; company transparency and business ethics issues; publicizing corporate information and corporate social responsibility policies and practices.

Angyal (2009) sees that CG and CSR are intertwined "neither intersection, nor intersection, nor parallelism, but coexistence". (Angel, 2009: 14). It does not agree with the incompatibility of corporate governance or corporate governance and social responsibility, in practice the former two are more common. Corporate governance encompasses corporate social responsibility policies, procedures, and can be interpreted as the relationship between governors and stakeholders. The authors of the studies analyzed agree that the two phenomena coexist and are connected at several points. The goals of the two phenomena are intertwined with compliance with other important requirements (environmental, labor law) besides the primary corporate goal.
\end{abstract}

Keywords: Corporate Social Responsibility, Corporate Governance, multinational companies.

(JEL Classification: G30; G39, M14 )

\section{INTRODUCTION}

Corporate Governance (CG) is the system of big companies that includes corporate social responsibility (CSR) policies and procedures. CG in Hungarian means social responsibility, more specifically corporate steering. The term, responsible corporate governance, is often used in Hungarian literature. In addition, the corporate word appears meaning company, so the word composition is also used as responsible corporate governance (Kecskés, 2011).

CG or company management has been known for more than 150 years in the management of business organizations and was included in the management literature as a concept. CG is often interpreted in many ways. Fayol already distinguished it in 1918 as the most important factors of government such as owners, directors, CEOs and their tasks (Fayol, 1984). One such definition states that the relationship between shareholders, management, public authorities, and supervisors or any other person and organization interested in the operation can be called corporate governance. On the other hand, CG creates and adheres to the principles and rules that govern and limit the people who act on behalf of 
the company (Peter Druckert, 1993 in Angyal, 2001). One of the other definitions that identify governance with leadership states that governance means, which policies the company pursues and how governance manages and serves its interests (Wood, 1994- in Angyal, 2001).

Another CG definition is the organizational solution which represents and serves the interests of the company's investors (Mayer, 1995 in Angyal, 2001). In every country and age, corporate governance has been defined as the set of rules that have allowed the oversight of companies (O. Pastré, 1994 in Angyal, 2001), CG (solution) is the system by which companies are managed and regulated (Sir Cadbury, 2000 in Angyal, 2001). Based on the definition of the German Corporate Governance Code, the concept of corporate governance and social responsibility already seems to be linked. The Codex regards the continuous increase of the value of the company as the essence of governance and sets out three target systems: 1) legitimate, lawful behavior, 2) economic gain, and 3) moral and social responsibility.

Corporate governance or responsible corporate governance is the systems of big companies; a system based on the sharing of power and roles between owners, management and boards (board and supervisory board). According to the roles, ownership, supervision, and leadership roles are separated. The division of power in this definition means that the syndicates keep the management under strict control and these syndicates are accountable to the owners (Tasi, 2012). According to Tasi (2012), responsible corporate governance involves careful management; financial planning and implementation; control mechanisms for the operation of the company; company transparency and business ethics issues; publicizing corporate information and corporate social responsibility policies and practices. Angyal sees that CG and CSR are intertwined in a "neither intersection, nor junction, nor parallelism, but in a co-existing faze which prevail above all." (Angyal, 2009: 14). He does not agree with the incompatibility of corporate governance with social responsibility. Furthermore, according to Angyal (2008), governance and responsible behavior can be interpreted by observing the relationship between governors, syndicates and stakeholders.

\section{MATERIALS AND METHODS}

Interpreted at the level of large companies, CG means: the long-term goal of securing the growth of investor wealth, meeting the needs and expectations of the social environment, harmonizing economic and non-economic goals, and ensuring global competitiveness in line with the mentioned above three. According to Angyal (2001), CG can be described by the following concepts: the stakeholders' relationship with one another, regulation of corporate life, and the allocation of power within the company, shared power, special organizational solution, associate management, and collaboration between them. By interpreting the concept of corporate governance, Angyal continues Chikán's (2000) idea that the consumer is not a king but a partner, but winning him is a prerequisite for the survival of the company and adds two more points to company management, investor confidence and social satisfaction (Angyal, 2001).

According to Auer (2017), corporate governance and corporate social responsibility are linked at several points. His point of view is that corporate governance is an "inside system focusing on the internal structural mechanisms of the company", while corporate social responsibility is focused on "extern processes", taking into account non-statutory ethical standards (Auer, 2017: 27). The goals of the two phenomena are linked so those in both cases, besides the primary goal of the company (profit maximization), the completion of other requirements (environmental protection, labor law, etc.) are important. Corporate governance has emerged in the specialized literature as a response to corporate scandals, while social responsibility involves more complex problems than solutions to environmental, economic, and societal difficulties (Auer, 2017).

Braun (2015) regards corporate governance as one of the areas of social responsibility, while Kun (2009) regards corporate governance as a system of corporate social responsibility within the company.

According to Auer (2017), responsible corporate governance and corporate social responsibility appear at different levels within the company, and at the strategic and operational levels, if appropriate behavior is established in these areas, corporate governance will also work effectively.

Effective corporate governance can be achieved by adhering to the principles of business and ethics, in which much depends on the impeccable, and moral integrity of the leaders.

Moral principles cannot be disregarded from business operations, and compliance with basic moral laws prevents the person responsible for corporate governance from acting. Rules-based corporate governance should not be opposed to ethical leadership, and in this the moral power of economic factors plays a major role.

\section{RESULTS AND DISCUSSION}

The evolution of corporate governance is also a new area for economic historians, writes Herrigel (2006). In addition, he says that CG (Corporate Governance, Corporate Steering) refers to the processes that shape the relationship between company owners and management.

Based on the OECD guidelines (2004), good corporate governance is the rules and practices that guide the relationship between the company, managers and shareholders, as well as stakeholder relations, such as employees and creditors, who contribute to growth, financial stability, market confidence, strengthening the financial market integrity and economic efficiency.

Corporate Governance research by Herrigel (2006), OECD Principles (2004), Kirkpatrick (2009), Zandstra (2002), Alpaslan (2009), Johnson and Greening (1999), and Fama (1980), has highlighted that knowing the characteristics and evolution of corporate governance not only helps us 
better understand the dynamics of companies' performance and economic development, but also how the events of the company and the political and legal order change and relate. Herrigel (2006) presents the historical evolution of the corporate governance system of five countries (United States, United Kingdom, Germany, France, and Japan) and discusses corporate governance in a chronological order within a given country and, at the same time, the crosssectional differences between countries. Countries are grouped by the author according to concentrated and diffuse ownership systems, and corporate ownership is embedded in social, institutional and power systems. Herrigel described the features of a concentrated and scattered ownership system. In the concentrated case, he wrote about weak securities markets, owners controlling large blocks of shares, low market transparency, limited role of the corporate market, and the monitoring function of large banks. The diffused ownership system is the opposite of the former, where it refers to strong securities markets, strict requirements for corporate information provision, market transparency, and an active corporate market.

The OECD Principles of Corporate Governance (2004) provides policy-makers, regulators and market players with specific guidance to improve legal and regulatory framework conditions that underpin corporate governance, as well as advice on stock exchanges, investors, organizations, and other parties involved in the process of developing good corporate governance. The Principles cover six important areas of corporate governance that provide the basis for an effective governance framework: 1) shareholder rights, 2) equitable management of shareholders, 3) the role of stakeholders in corporate governance, 4) disclosure, 5) transparency, and 6) the responsibility of the board of directors. The key to the success of the Principles is that they are fundamentally based and non-prescriptive, so they can retain their validity in changing legal, economic and social contexts. The necessary legal / regulatory framework is an essential requirement to support effective corporate governance, which should be an integral part of the Principles. On the other hand, the aim is to create an effective system of brakes and balances between the board and the management. Managers have a key role in multiowned companies, and monitoring is required to avoid potential misuse of their positions.

Kirkpatrick (2009) says that the post-2000 market and macroeconomic environment is the one that expects the corporate governance system to be: management boards need to be aware of the company's strategy and risk appetite; in order for these to be compatible with corporate goals and risk appetite. Kirkpatrick formulates the concept and purpose of enterprise risk management (ERM): “The process influenced by the board of directors, the management, and other actors in the corporate staff, is used in the strategy-making process for the whole company, used to identify potential events that may affect the entity and manages the risk within the limits of risk appetite, in order to gain reasonable assurance on the achievement of the entity's goals."
The ERM consists of eight components:

- External environment: it encompasses the nature of the organization and provides a basis for managing the risk and for which members of the entity are involved;

- Target designation: The goals had to be formulated before the management can identify potential events that affect their targeting;

- Event identification: it is necessary to identify external and internal events that affect the entity's goal achievement, distinguishing between risks and opportunities;

- Risk assessment: risk analysis is carried out with regard to the probability and impact as a basis for deciding how to manage them;

- Risk response: management selects risk responses by planning a series of actions, sorting out risks according to the entity's risk tolerance and risk-hunger;

- Control actions: procedures and policies are set up and implemented to ensure that risk responses are effectively carried out;

- Information and communication: relevant information is identified, acquired and communicated throughout the organization in a form and timeliness that enables people to assume their responsibilities;

- Monitoring: The completeness of the company's risk management is monitored and changes can be made if necessary.

According to Kirkpatrick (2009), ERM becomes visible in three dimensions: the goals, the totality of the company and the framework. Defining goals proceeds: strategic, operational, meaning efficient and effective use of resources, reporting that includes reliability and consistency with applicable laws and regulations. These can be applied at enterprise, division, business unit and subordinate levels.

Zandstra (2002) claims that the company may fail if the board cannot operate morally and ethically. He mentions the failure of Enron as an example. President Bush at this time worked out a plan to clarify the core issues of corporate responsibility, but he forgot to take into account one of the important weaknesses of corporate governance, says Zandstra (2002), whose duty is to oversee the company, to trust the public and the shareholders, and to build trust with his actions. Corporate governance is also the responsibility of the investors and the monitoring of the company law. Enron would not have been saved by a new set of regulations or new versions of laws or accounting practices. Examining the fall of Enron, Zandstra believes that as long as all companies are governed by state law, the state has no legal requirements for eligibility for board membership.

The boards must have at least 3 functions:

- The Board is responsible for providing the company with the air of legitimacy. Members must be people with expertise and business experience. Their affiliation with the company must be trusted, awaken to those who buy the company's shares;

- Focuses on auditing and legal requirements. Auditing is usually done by the Audit Committee, which is a department of the Management Board; 
- Administrative role. The Board of Directors is expected to define, amend and approve the business plan. Corporate executives are responsible for entering into a dialogue with the board of directors, for supplying and executing the decisions of the board giving them the necessary inputs if the situation requires it.

Zandstra (2002) highlights an important element of corporate governance, and claims that a company may be prevented from collapsing by a properly functioning board of directors, if its members are willing to take their ethical responsibility seriously for their shareholders and their public responsibility.

Alpaslan (2009) believes that many of the traditional corporate governance thinkers agree that within legal constraints and ethical practices, the only duty of managers is to maximize shareholder value (Friedman 1970, Jensen \& Meckling 1976, Vidaver-Cohen 1998: 395- 397, Jensen 2002 in Alpaslan 2009). He asks what happens in the context of a conflict or a crisis when someone tries minimizing the loss of stakeholders with the goals of maximizing shareholder value. In line with the traditional corporate governance principle, managers can only minimize the losses of stakeholders if they maximize shareholder value without violating the legal rules and ethical practices of society.

Alpaslan points out that although the shareholder model dominates corporate governance practices (Bradley et al. 1999, Margolis and Walsh 2003: 271 in Alpaslan, 2009), it is still unable to provide satisfactory guidance in a crisis situation.

Corporate Governance Share Ownership is incapable of ethically answering the question of "how can companies be governed in the context of the crisis"? (Alpaslan 2009: 49). It can be stated that the stakeholder model seems to be an ethically more suitable corporate governance choice in the context of crises, unlike the shareholder model, which begins to maximize shareholder value and treats ethical considerations as a constraint; which from the start, includes ethical considerations.

Economists dealing with company theory (Baund, 1959; Simon, 1959; Cyert \& March, 1963 in Fama 1980) are concerned with the incentive problems that arise when decision-making is the responsibility of executives who do not belong to the company's securities holders. Examples include behavioral and managerial company theories (Fama, 1980), which reject a model that favors profit maximization and considers it important to seek to motivate business leaders who manage but at the same time are not owners.

The theories introduced by Fama (1980) also favor the positive attitude of entrepreneurs towards CSR, because the company's behavioral model does not seek to maximize profit in the classical sense, but gives space for further motivation factors of the existence of the company, such as employment policy, cooperation with stakeholders, continuity of philanthropic activities. On the other hand, management company theory does not assume information asymmetry, but that the market, as to call it, the manager market, sets limits and opportunities against the services of company managers, so it focuses on motivation, so besides the personal interest of the manager, the collective interest of the company also prevails, this way, the chances of abuse on the part of the company managers are reduced.

According to another approach dealing with corporate theory (Alchian \& Demesetz, 1972 \& Jens- Meckling, 1976 in Fama 1980), the company is considered to be a set of contracts between production factors. The company is considered a team where members act on their own behalf, but their fate depends on the survival of the team, in a competition where they compete against other teams. In classical theory, the operator who impersonates the company is the entrepreneur, who is the one-to-one manager and the residual risk bearer. Alchian \& Demesetz calls the entrepreneur the employer, but this does not explain the management of large companies, where corporate governance is carried out by managers who are separate from the company's securities holders.

Fama (1980) considers the concept of corporate ownership irrelevant and explains it as follows. Management is a workforce with a special role, coordinating the operation of inputs and fulfilling contracts concluded between inputs, so it is present as a decision maker. It explains the role of risk takers by assuming that the company leases all other production factors and contracts are made at the beginning of the production periods, while payments are due at the end of these periods. In this context, he assumes two scenarios. 1. If production factors have to be paid always at the end of the period, the risk taker does not have to invest anything at the beginning of the period, it is assumed that this is guaranteed by concluding a fund at the beginning of which capital and technology can be obtained. 2. When a committed fund is created by issuing bonds and ordinary shares, bonds embodying a combination of risk-taking and ownership of capital bear a lower risk than ordinary shares. Thus, the company is the set of contracts that record how to combine inputs to generate outputs and how to distribute revenues from outputs between inputs. In this contractual relationship, Fama (1980) says the ownership of the company is an irrelevant concept.

Fama (1980) separates company management and risk-taking as well as securities ownership and corporate governance. In theory the classical company is the entrepreneur who is in one person a manager and has a risk taking role in the company analysis. He sees the disadvantage of management and risk-taking in that both of its services appear on a market that offers alternatives. Risk takers have markets for their services, capital markets; where they can switch teams with low transaction costs, many companies distribute their funds among the securities, so as not to be overburdened by a company's assets. The task of the management of the company is to control the contracts between the factors of production and the viability of the company. For the manager market, past failures and successes of the company leader provide information, so in the present situation the success / failure of the team managed by it influences its future salary, thus becoming interested in the success of the company. Fama's comments on the viability 
of separating securities ownership and corporate governance are as follows. The external manager's labor market has a significant impact on companies to select and pay managers based on performance, if the corporate reward system is not performance-sensitive, then the company loses its managers. On the other hand, the internal monitoring of managers by their colleagues is also significant. It is in the interests of senior management to pursue policies that give the manager the most positive signal to the labor market. He asks the question how to discipline the top management, the board assigned to it is the Board of Directors, but how to set it up to perform its task properly. Management by securities owners does not seem to be a good solution because they share resources among many companies, so it is not in their best interest to be sure about the company's best destiny. Another scenario is that senior managers are best placed to manage the board because they are the most informed and sensitive critics of the company's performance and furthermore the board can be expanded with external expert directors. We can conclude that, the system of ownership unbundling and corporate governance is consistent with the pressure exerted by the managerial market and is also in the interest of the securities holders, and this may seem to be a good separation.

Jensen (2002) criticizes the interest-bearing theory, explaining that it contradicts the unequal purpose of organizations. In the following, I discuss the incompatibility of Jensen's (2002) value maximization versus interest-bearing theory. According to value maximization, managers have to make all their decisions to increase the company's longterm market value. The total value is the sum of the value of financial claims related to the company, including share capital, loan capital, preferred shares and guarantees. In contrast with this, stakeholder theory says managers need to make their decisions to take into account the interests of the company's stakeholders. According to Jensen (2002), who is the rival of the theory of interest and of the value maximization principle which, however, cannot be considered as a complete specification of the corporate circumstance or target function. It serves the individual interests of those who have embraced, including many outside companies, many corporate managers and directors. According to Jensen (2002), interest-bearing theory is inherently flawed because it violates the point that every organization should have a unified goal. He claims that if a company adapts the interest-bearing theory, it will be at a disadvantage in the race for survival, because the interest-bearing theory politicizes the company and empowers the managers to follow their own preferences when using the company's resources.

Jensen (2002) explains the misconception of interestbearing theory with the following: it is impossible to maximize in more than one dimension at the same time unless the dimensions are monotonous transformations of one another. As an example he mentions if the manager gets the job to maximize current profit, market share, future profit growth, and anything else he likes, he is in a position where he cannot make a grounded decision -simply put he remains without a goal. This is explained by the fact that representatives of stakeholder theory often receive active support from managers who want to weaken the strength of the constraints of valueseeking, capital market empowerment, corporate governance which are products of the markets. He also argues that more political action limits the power of markets restricting the managers too. Such persons will continue to use the arguments of interest-bearing theory to legitimize their own position.

Stenberg (2009) makes critical statements against corporate definitions, corporate responsibility and conventional definitions of business ethics.

Corporate social responsibility advocates, as they see fit, generally do not support submitting corporate goals. CSR advocates clearly place social responsibility at the forefront of corporate and business interests pushing these into the background. While other CSR supporters seem to support the pursuit of corporate and business goals, the interests of stakeholders are prevalent against shareholders. If only shareholders do not agree into some extent of change - this is a direct violation of corporate governance, even if it was initiated by the company managers or the board of directors (Stenberg, 2009).

Conventional CSR and interest-bearing doctrine fit well according to Stenberg (2009) and serve well authoritarian and collectivist goals together. The dimensional connection of the two sides leads to superficial credibility, and the apparent generosity that they generate encourages people to accept the relationship uncritically.

Business ethics is about how we conduct business according to ethical expectations. This means that we follow the business goals and meet two well-defined limits. One such limit, which must be met due to the business objective, is to maximize shareholder value over the long term. Future long-term goals require conviction, and confidence is achieved through trust, and consequently compliance with constraints is a prerequisite for trust. As an example, that ownership value assumes ownership and the second limit involves the respect of the rights of the owners. In the light of these constraints, the business must be guided fairly in order to meet ordinary fairness and justice. As with business ethics, social responsibility also has a meaning but is very different from what it is conventionally assumed. When interpreted correctly, social responsibility does not apply to the responsibility of the institutions for the interest-bearers. Instead, he speaks more about the responsibility of the stake holders to reflect their appreciation of their business in their social activity. Social responsibility is manifested when individuals' values are reflected in their actions, whether they pursue their activities alone or in a community (Stenberg, 2009).

Corporate governance encompasses corporate social responsibility policies, procedure, and can be interpreted as the relationship between governors and stakeholders. The authors Angyal (2009) and Auer (2017) agree that the two phenomena coexist and are connected at several points. The goals of two phenomena are intertwined with compliance with other important requirements (environment, labor law) besides the primary corporate goal to maximize shareholder value. 


\section{REFERENCES}

Alpaslan, C, M (2009): Ethical Management of Crisis, Shareholder Value Maximisation or Stakeholder Loss Minimisation?, Journal of Corporate Citizenship, Winter 2009, 41-50 pp

Angyal, Á. (2001): Vállalati kormányzás (corporate governance) Aula Kiadó, Budapest

Angyal, Á. (2009): Vállalatok társadalmi felelőssége, felelős társaságirányítás (corporate social responsibility), Kossuth Kiadó, Budapest

Angyal, Á. (2008): Vállalatok társadalmi felelőssége- Versenyképesség Kutatások Múhelytanulmány Sorozat, Versenyben a világgal 20072009 címú kutatás, Budapesti Corvinus Egyetem, Vállalatgazdaságtan Intézet, Versenyképesség Kutató Központ, p.1-78

Auer, Á. (2017): Corporate governance A felelôs társaságirányítás jelenkori dimenziói, Dialóg Campus Kiadó, Budapest

Braun Róbert (2015): A vállalati társadalmi felelősségvállalás, Akadémiai Kiadó, Budapest

Chikán, A. (2008): Vállalati versenyképesség és társadalmi felelősség, Harward Business Review Magyar Kiadás, 2008. november pp.6-13

Fayol, H. (1984): Ipari és általános vezetés. Közgazdasági és Jogi Könyvkiadó, Budapest, 1984

Herrigel, G.(2006) „Corporate Governance: Histoy without Historians"in ed. Geoffrey Jones andJonathan Zeitlin, Handbook of Business History (Oxford: Oxford University Press, 2006).

Jensen, M. C. (2002): Value Maximization, Stakeholder Theory and the Corporate Objective Function. Business Ethics Quarterly, vol.12, No.2, pp.235-256.

Kecskés, A.(2011) Felelős társaságirányítás (Corporate Governance ) HVG-ORAC, Budapest

Kirkpatrick, G (2009):Corporate governance lessons from the financial crisis, OECD Journal: Financial Market Trends Vol 2009 Issue 1, 61-68 pp.

Kun, A. (2009) A multinacionális vállalatok szociális felelőssége, Ad. Librum Kiadó, Budapest

OECD Principles of Corporate Governance 2004, Policy Brief OECD August 2004 OECD Observer

Stenberg, E. (2009): Corporate social responsibility and corporate governance, Institute of economic Affairs, Published by Blackwell Publishing, Oxford

Tasi. M. (2012) Vállalati irányítási rendszerek, TÁMOP-4.1.2 A1 és a TÁMOP- 4.1.2 A2 könyvek

Zandstra, G (2002): Enron, board governance and moral failings, Corporate Governance Vol 2, Number 2, 16-19 pp, The international journal of business in society ISSN:1472-07101, Online form:2001 
